\title{
Study on genetic diversity in chilli (Capsicum annuum) based on multivariate analysis and isozyme analysis
}

\author{
Chandan Kumar Mondal ${ }^{1,2^{*}}$, Pinaki Acharyya ${ }^{1}$ and Uttam Saha ${ }^{1,3}$ \\ ${ }^{1}$ Department of Horticulture, Institute of Agricultural Science, University of Calcutta, Kolkata - 700019 (West Bengal), \\ INDIA \\ ${ }^{2}$ Present Address: Ramkrishna Ashram KVK, Nimpith, South 24 Parganas - 743338 (W.B), INDIA \\ ${ }^{3}$ Present Address: Department of Agriculture, Govt. of Tripura, Amarendranagar- 799103 (Tripura), INDIA \\ ${ }^{*}$ Corresponding author. E-mail: drchandanmondal@gmail.com
}

Received: February 10, 2016; Revised received: July 28, 2016; Accepted: October 24, 2016

\begin{abstract}
Thirty seven diverse chilli (Capsicum annuum) genotypes were studied for 22 growth, yield and fruit quality traits. Multivariate analysis grouped the genotypes into 7 clusters. Cluster IV was largest containing 14 genotypes. Inter cluster distance was maximum between cluster V and VII (248.09), and minimum between cluster I and II (57.80). Cluster VII was most heterogeneous (intra-cluster divergence value 191.25) and Cluster II was most homogeneous (30.25). Genotypes were also analyzed for peroxidase enzyme polymorphism using gel electrophoresis which resulted seven electrophoretic bands (Rf 0.19 to 0.59) and grouped the genotypes into 6 zymotypes. Zymotype $\mathrm{P}_{4}$ included maximum (13) number of genotypes. Number of clusters in peroxidase and multivariate analysis were almost same but distribution of genotypes varied. $73 \%$ of total genotypes showed similar pattern of grouping suggesting that the two methods are complementary to each other and should be carried out simultaneously to determine genetic diversity more effectively. Considering variability and diversity analysis of the genotypes, $\mathrm{CUCH}-4$ from Cluster-II (\& Zymotype- $\mathrm{P}_{2}$ ) and $\mathrm{CUCH}-31, \mathrm{CUCH}-34$ and $\mathrm{CUCH}-35$ from Cluster-VII (\& Zymotype-P4) were identified as promising genotypes which can be used in further crop improvement programme.
\end{abstract}

Keywords: Capsicum, Chilli, Diversity, Multivariate analysis, Peroxidase analysis

\section{INTRODUCTION}

Chilli is an important commercial crop cultivated exclusively in tropical and temperate zones of the world and grown on more than 1.5 million hectares worldwide (Anonymous., 2007). Chilli finds its place as vegetable, spice and condiment. It is useful in pharmaceuticals also. India is the largest producer, consumer and exporter of chili, which contribute around $25 \%$ of total world production. After India, China is the major producer of Chili in the world (Anonymous, 2012). However, productivity of chilli in India is almost half than that of China (Ali, 2006). Identification of a genotype better suited for a particular region as well as it's improvement in all aspects is of immediate task. Genetic improvement of any crop depends on magnitude of genetic variability and the extent of heritability of economically important characters. Critical assessment of nature and magnitude of variability in the germplasm stock is one of the important prerequisites for formulating effective breeding methods. The higher genetic distance between parents, the higher heterosis in progeny can be observed (Lahbib et al., 2012). Traditionally, characterization and variability evaluation of a genetic stock is done by a combination of morphological and agronomic traits. However, this approach is prone to environmental influences (Peeraullee
\& Ranghoo-Sanmukhiya, 2013). The isozyme markers have been useful in determining genetic relationships among closely related species and cultivars (Aniel Kumar et al., 2013). Although morphological traits and isozyme marker analysis have been used to distinguish cultivars, both systems have limitations, the first due to environmental effects (Bhat et al., 1992a,b) and the latter due to selection of markers. Isozyme electrophoresis is chosen for its relative simplicity because it provides direct visualization of gene products (Brewer and Sing, 1970) and potentially can provide a unique fingerprint for each genetically distinct clone (Lebot et al., 1991). In chili pepper such studies on isozymes are very limited (Gupta et al., 1997; Onus and Pickersgill, 2000; Barrera et al., 2005). Nitesh et al. (2010) reported varietal identification of chilli peppers by PPO isozyme profiles. However, in depth studies on polymorphism of isozyme for assessing intravarietal relationships in chilli peppers is very limited (Aniel Kumar, Subba Tata, 2013).

The present study was aimed at assessing 37 chilli genotypes based on 17 morphological and 5 biochemical traits, grouping of genetically similar genotypes and further verification of this diversity analysis using peroxidase isozyme polymorphism analysis through gel electrophoresis. 


\section{MATERIALS AND METHODS}

Field trial: The 37 chilli genotypes were collected from different locations as mentioned in Table- 2 and evaluated for three consecutive years (2007-08, 200809, 2009-10) following randomized block designs with three replications. Pre-soaked seeds of all the genotypes were sown in seedbed in the first week of November each year. 45 days old seedlings were transplanted in the main field in the individual plots with a spacing of $45 \mathrm{~cm} \times 45 \mathrm{~cm}$ ensuring 40 plants in each plot. Transplanting was done by $2^{\text {nd }}$ fortnight of December each year. Essential intercultural operations (weeding, staking, time bound irrigation, plant protection measures etc.) were carried out as and when required. Seventeen morphological and five biochemical traits were selected for study following descriptor of Capsicum (IPGRI, 1995).

Multivariate analysis: The genetic divergence was calculated following Mahalanobis $\mathrm{D}^{2}$ statistics (Mahalanobis, 1936). Multivariate analysis or $\mathrm{D}^{2}$ analysis is a method for grouping genetically similar germplasms. It has been observed that for varieties development programme, it is desirable to classify the germplasm on the basis of diversity of different characters and to make crosses between groups having maximum diversity (Narasimhayya and Venkatarao, 1974).

Peroxidase isozyme analysis: The analysis was conducted taking leaf extract of $2^{\text {nd }}$ or $3^{\text {rd }}$ leaf of 60 days old plant. $500 \mathrm{mg}$ leaf sample was crushed in $2.5 \mathrm{ml}$ phosphate buffer $\left(\mathrm{pH} 6.8 ; \mathrm{K}_{2} \mathrm{HPO}_{4}\right.$ solution - $6.15 \mathrm{ml}$ and $\mathrm{KH}_{2} \mathrm{PO}_{4}$ solution - $3.85 \mathrm{ml}$ dissolved in $100 \mathrm{ml}$ water) in a pre-chilled mortar \& pestle. The crude homogenate was centrifuged at $14,000 \mathrm{rpm}$ at $4^{\circ} \mathrm{C}$ for 20 minutes. The supernatant was transferred into fresh tubes and divided into two parts. One part was used for protein estimation.

Protein estimation: Dried test tubes, cleaned with distilled water and alcohol, were marked according to the sample accession numbers. One was marked as blank. In each test tube $10 \mu \mathrm{l}$ cold tissue extract, 990 $\mu 1$ phosphate buffer and $5 \mathrm{ml} \mathrm{G} 250$ dye were added. In the blank, instead of tissue extract, $10 \mu$ l distilled water was added. The mixtures turned deep blue in colour immediately. Sample and blank were taken in two different cuvates and absorbance was estimated using a spectrophotometer (Makeup Jasco, Model-V630) at $595 \mathrm{~nm}$. Protein content in each sample was calculated as per absorbance values against standard curve prepared using standard protein (BSA).

Peroxidase analysis was conducted in polyacrylamide gel (PAGE) system. The tissue extracts were taken in required amount after calculating its protein content. Vertical electrophoresis unit was used to run the gel.

Gel preparation: Gel was prepared in a dark conical flask having $12.2 \mathrm{ml}$ water, $10 \mathrm{ml} \mathrm{30 \%} \mathrm{Acrylamide}$ mix, $7.5 \mathrm{ml}$ Tris- $\mathrm{HCl}$ ( $\mathrm{pH} 8.8$ ), $300 \mu 1$ 10\% APS and $20 \mu \mathrm{l}$ TEMED. It was $10 \%$ Tris-Glycine Polyacryla- mide gel solution.

Electrophoresis: The gel was ready in $1 \mathrm{hr}$. The gel plate was placed in the tank after pouring the tank buffer (Tank buffer prepared with Tris (1.2 g) and glycine $(5.8 \mathrm{~g})$ dissolved in $100 \mathrm{ml}$ distilled water and the volume was made upto $200 \mathrm{ml}$ and diluted 10 times). Now, $32 \mu \mathrm{l}$ of sample extract and $8 \mu \mathrm{l}$ Bromophenol blue dye were mixed and added carefully at the comb places at top of the gel. Then electrophoresis was carried out at 15 Amp. \& 150 volt, approximately for 5 hrs until bromophenol blue reached the gel end. The gel was stained for peroxidase.

Staining: Gel plates were taken out, the gel was separated carefully and it was dipped in staining solution (100 mg ortho-dianisidine dissolved in $1 \mathrm{ml}$ of Acetic acid; $200 \mathrm{ml}$ of water and $2 \mathrm{ml}$ of $\mathrm{H}_{2} \mathrm{O}_{2}$ added to it) horizontally and kept in dark for 30 minutes with occasional shaking. The bands of peroxidase developed. After staining, the gel was washed with distilled water and photographed by a gel documentation system (Multidoc, UVP) for band identification and final calculation.

Band analysis: Isozyme banding patterns were analyzed on the basis of number and Relative front (Rf) values of the bands. The $\mathrm{Rf}$ value is the mobility of each band travelled from the origin divided by the migration of tracking dye (Powers et al., 1988). Similarity coefficient values of electrophoretic pattern of each enzyme were subjected to cluster analysis employing the unweighted pair group method using arithmetic averages (UPGMA). For cluster analysis, value ' 1 ' was put for the presence and ' 0 ' for absence of the band for each genotype. Zymotypes were used for clustering and the Euclidean distance method (Nourish, 1993) was used for the dissimilarity.

\section{RESULTS AND DISCUSSION}

The present study aimed at determining the genetic divergence of the 37 genotypes employing 22 important characters pertaining to growth, fruit yield components, proximate compositions of leaf and fruit and per plant fruit yield (Table 1).

Multivariate analysis: Following $\mathrm{D}^{2}$ statistics 37 genotypes were meaningfully grouped into 7 clusters (Table 2). It was found that the clustering pattern was, in general, not related to geographic origin of the genotypes which was in conformity with the earlier findings of Murty and Arunachalam (1966), Varalakshmi and Babu (1991), Pandey and Dobhal (1993) and Sreelathakumary and Rajamony (2004). However, some genotypes having similar place of origin were grouped in the same cluster like $\mathrm{CUCH}-22$ and $\mathrm{CUCH}-23$ in Cluster IV. Hence, implication of geographical origin on genetic diversity may not altogether be ignored.

Cluster-IV was the largest containing 14 genotypes followed by cluster VII and II having 8 and 7 genotypes in each respectively. Rest four clusters (cluster-I, 
Chandan Kumar Mondal et al. / J. Appl. \& Nat. Sci. 8( 4): 1884-1892 (2016)

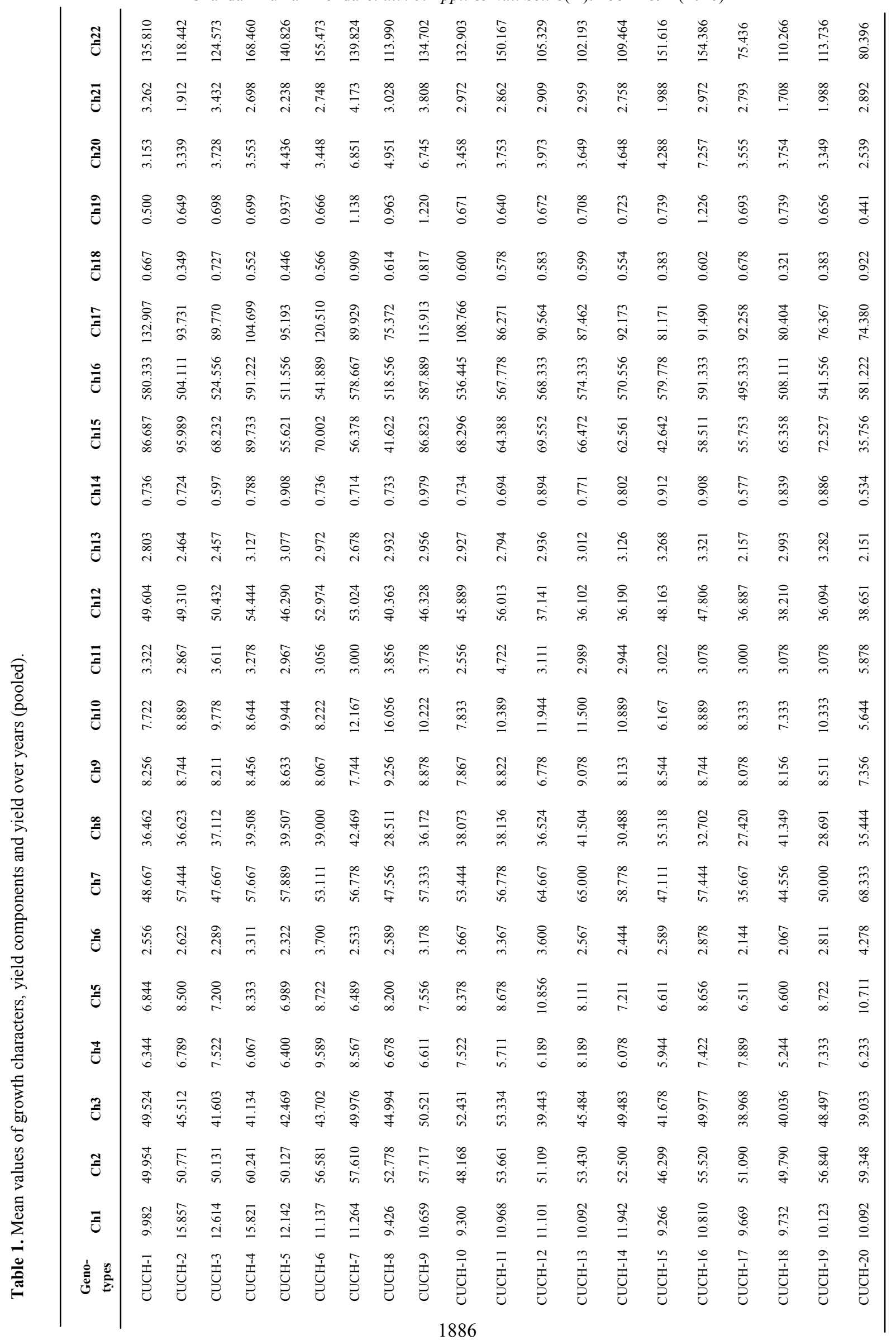


Chandan Kumar Mondal et al. / J. Appl. \& Nat. Sci. 8( 4): 1884-1892 (2016)

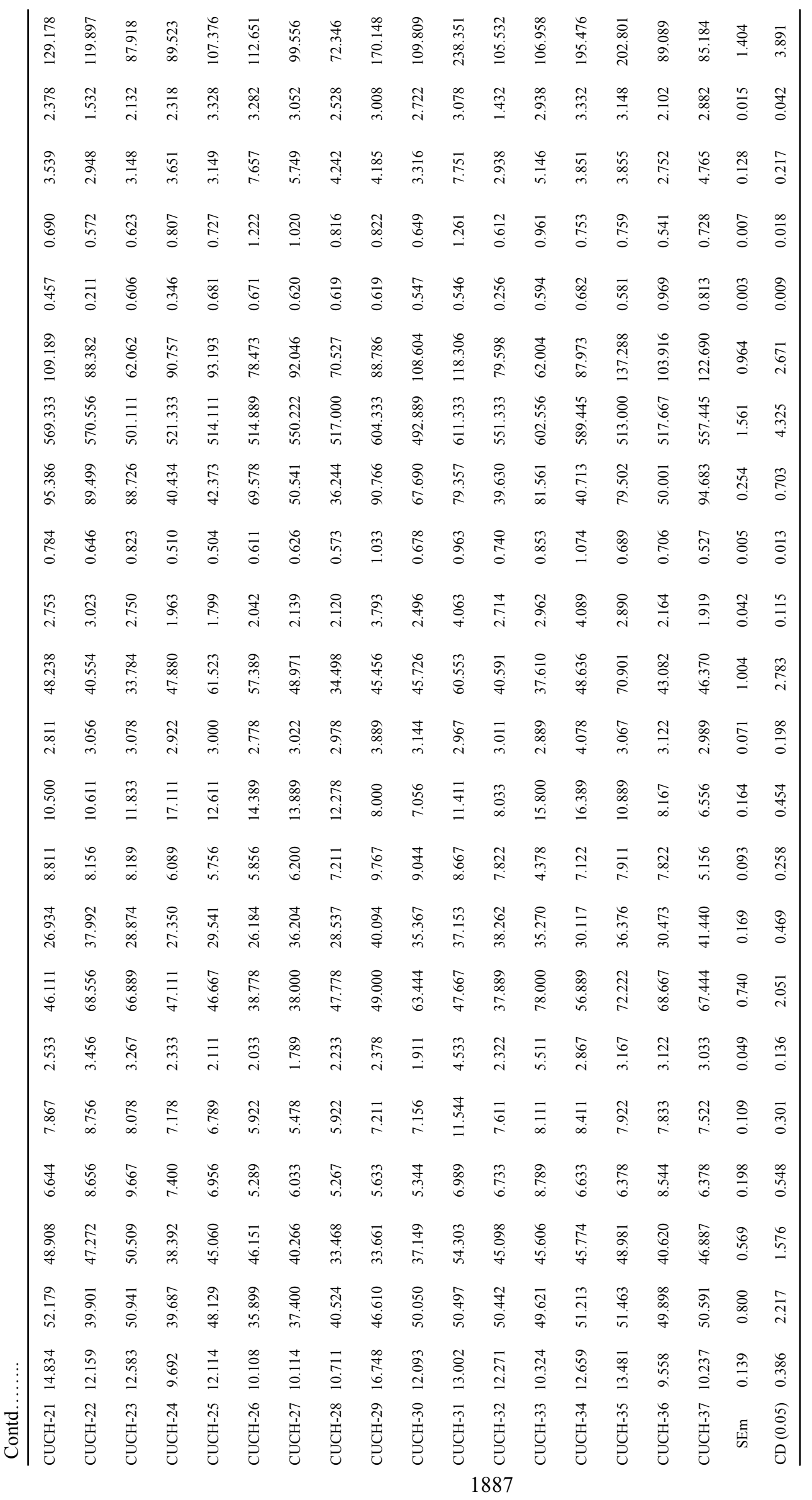


Table 2. Grouping of 37 genotypes in Clusters (Pooled analysis).

\begin{tabular}{|c|c|c|c|}
\hline Cluster & $\begin{array}{c}\text { No. of } \\
\text { genotypes }\end{array}$ & Genotypes & Place of Collection \\
\hline \multirow[t]{2}{*}{ CLUSTER I } & 2 & CUCH-11 & Horticultural Research Station, Lam, Guntur, A.P. - 522034 \\
\hline & & CUCH-13 & Horticultural Research Station, Lam, Guntur, A.P. - 522034 \\
\hline \multirow[t]{7}{*}{ CLUSTER II } & 7 & CUCH-1 & AICRP-Vegetable Crops, Directorate of Research, B.C.K.V., Kalyani, WB \\
\hline & & $\mathrm{CUCH}-2$ & AICRP-Vegetable Crops, Directorate of Research, B.C.K.V., Kalyani, WB \\
\hline & & $\mathrm{CUCH}-3$ & AICRP-Vegetable Crops, Directorate of Research, B.C.K.V., Kalyani, WB \\
\hline & & CUCH-4 & AICRP-Vegetable Crops, Directorate of Research, B.C.K.V., Kalyani, WB \\
\hline & & $\mathrm{CUCH}-5$ & AICRP-Vegetable Crops, Directorate of Research, B.C.K.V., Kalyani, WB \\
\hline & & CUCH-6 & AICRP-Vegetable Crops, Directorate of Research, B.C.K.V., Kalyani, WB \\
\hline & & CUCH-10 & AICRP-Vegetable Crops, Directorate of Research, B.C.K.V., Kalyani, WB \\
\hline \multirow{2}{*}{$\begin{array}{l}\text { CLUSTER } \\
\text { III }\end{array}$} & 2 & CUCH-17 & Local collection by KVK, Nimpith, South 24 PGS, W.B. - 743338 \\
\hline & & CUCH-24 & Local collection from Dalkhola, Uttar Dinajpur, W.B \\
\hline \multirow{14}{*}{$\begin{array}{c}\text { CLUSTER } \\
\text { IV }\end{array}$} & 14 & CUCH-7 & AICRP-Vegetable Crops, Directorate of Research, B.C.K.V., Kalyani, WB \\
\hline & & CUCH-8 & AICRP-Vegetable Crops, Directorate of Research, B.C.K.V., Kalyani, WB \\
\hline & & CUCH-9 & AICRP-Vegetable Crops, Directorate of Research, B.C.K.V., Kalyani, WB \\
\hline & & CUCH-12 & Horticultural Research Station, Lam, Guntur, A.P. - 522034 \\
\hline & & CUCH-14 & Horticultural Research Station, Lam, Guntur, A.P. - 522034 \\
\hline & & CUCH-15 & IARI, Pusa, New Delhi - 110012 \\
\hline & & CUCH-16 & $\begin{array}{l}\text { G. B. Pant University Of Agriculture \& Technology, Pantnagar, Udham Singh } \\
\text { Nagar, Uttarakhand - } 263145\end{array}$ \\
\hline & & CUCH-18 & Local collection by KVK, Nimpith, South 24 PGS, W.B. - 743338 \\
\hline & & CUCH-19 & Local collection by KVK, Nimpith, South 24 PGS, W.B. -743338 \\
\hline & & CUCH-20 & A.A.U., Jorhat, Assam \\
\hline & & CUCH-21 & A.A.U., Jorhat, Assam \\
\hline & & CUCH-22 & Local collection from Nagaland \\
\hline & & CUCH-23 & Local collection from Morigaon, Assam \\
\hline & & $\mathrm{CUCH}-25$ & Local collection from Dalkhola, Uttar Dinajpur, W.B \\
\hline \multirow[t]{2}{*}{ CLUSTER V } & 2 & $\mathrm{CUCH}-32$ & Amtala Seed Stores, Amtala, South 24 PGS, W.B. \\
\hline & & CUCH-36 & Local collection from Kuyemuri island, South 24 Pgs \\
\hline \multirow{2}{*}{$\begin{array}{l}\text { CLUSTER } \\
\text { VI }\end{array}$} & 2 & CUCH-30 & Amtala Seed Stores, Amtala, South 24 PGS, W.B. \\
\hline & & CUCH-37 & Local collection from Mandirbazar, South 24 PGS, W.B. \\
\hline \multirow{8}{*}{$\begin{array}{c}\text { CLUSTER } \\
\text { VII }\end{array}$} & 8 & $\mathrm{CUCH}-26$ & Local collection from Dalkhola, Uttar Dinajpur, W.B \\
\hline & & CUCH-27 & Local collection from Dalkhola, Uttar Dinajpur, W.B \\
\hline & & $\mathrm{CUCH}-28$ & Local collection from Aminpur, Hasnabad, North 24 PGS., W.B \\
\hline & & CUCH-29 & Amtala Seed Stores, Amtala, South 24 PGS, W.B. \\
\hline & & CUCH-31 & Amtala Seed Stores, Amtala, South 24 PGS, W.B. \\
\hline & & $\mathrm{CUCH}-33$ & Amtala Seed Stores, Amtala, South 24 PGS, W.B. \\
\hline & & CUCH-34 & Local collection from Canning, 24 Pgs.(S) W.B. \\
\hline & & CUCH-35 & Local collection from Damkal island, South 24 PGS \\
\hline
\end{tabular}

Table 3. Intra and Inter cluster distance among 37 genotypes.

\begin{tabular}{|c|c|c|c|c|c|c|c|}
\hline Cluster & $\begin{array}{c}\text { CLUSTER } \\
\text { I }\end{array}$ & $\begin{array}{c}\text { CLUSTER } \\
\text { II } \\
\end{array}$ & $\begin{array}{c}\text { CLUSTER } \\
\text { III }\end{array}$ & $\begin{array}{c}\text { CLUSTER } \\
\text { IV }\end{array}$ & $\begin{array}{c}\text { CLUSTER } \\
\mathrm{V} \\
\end{array}$ & $\begin{array}{c}\text { CLUSTER } \\
\text { VI }\end{array}$ & $\begin{array}{c}\text { CLUSTER } \\
\text { VII }\end{array}$ \\
\hline CLUSTER I & 66.578 & 57.800 & 82.870 & 148.928 & 99.142 & 59.537 & 198.739 \\
\hline CLUSTER II & & 30.250 & 72.308 & 135.492 & 97.659 & 59.747 & 181.388 \\
\hline CLUSTER III & & & 39.625 & 154.189 & 81.146 & 74.105 & 205.731 \\
\hline CLUSTER IV & & & & 184.468 & 182.851 & 150.558 & 197.269 \\
\hline CLUSTER V & & & & & 58.612 & 95.233 & 248.096 \\
\hline CLUSTER VI & & & & & & 66.408 & 201.711 \\
\hline CLUSTER VII & & & & & & & 191.254 \\
\hline
\end{tabular}

III, V and VI) had two genotypes in each (Table 2). The intra-cluster divergence was highly variable ranging from 30.25 in cluster II to 191.25 in cluster VII (Table 3). So, it may be said that cluster II, having 7 genotypes, is the most homogeneous group and cluster
-VII with 8 genotypes is the most heterogeneous group. High heterogeneity was also observed in cluster -IV showing high intra-cluster divergence (184.46). Inter-cluster distance was maximum ( $\mathrm{D}^{2}$ value 248.09 ) between cluster V and VII, suggesting wide diversity 
Chandan Kumar Mondal et al. / J. Appl. \& Nat. Sci. 8( 4): 1884-1892 (2016)

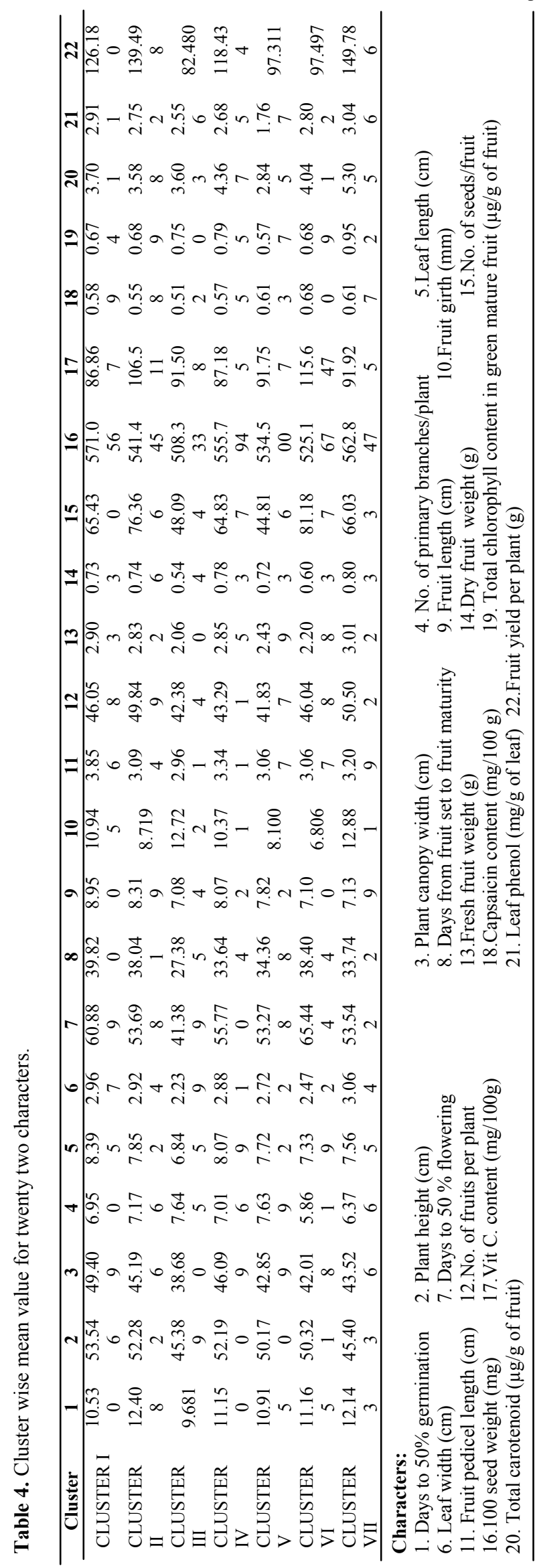

Table 5. Distribution of peroxidase bands among the zymotypes of 37 genotypes.

\begin{tabular}{|c|c|c|c|c|c|c|c|c|}
\hline \multirow{2}{*}{$\begin{array}{l}\text { Zymo- } \\
\text { types }\end{array}$} & \multicolumn{7}{|c|}{ Rf value of bands } & \multirow{2}{*}{$\begin{array}{l}\text { No. of } \\
\text { bands }\end{array}$} \\
\hline & $\begin{array}{l}0.1 \\
9\end{array}$ & $\begin{array}{l}0.2 \\
4\end{array}$ & $\begin{array}{l}0.4 \\
1\end{array}$ & $\begin{array}{l}0 . \\
44\end{array}$ & $\begin{array}{l}0.4 \\
9\end{array}$ & $\begin{array}{l}0.5 \\
4\end{array}$ & $\begin{array}{l}0.5 \\
9\end{array}$ & \\
\hline$\overline{\mathrm{P}_{1}}$ & $\sqrt{ }$ & $\sqrt{ }$ & $\sqrt{ }$ & & $\sqrt{ }$ & $\sqrt{ }$ & $\sqrt{ }$ & 6 \\
\hline $\mathrm{P}_{2}$ & & $\sqrt{ }$ & $\sqrt{ }$ & & $\sqrt{ }$ & $\sqrt{ }$ & $\sqrt{ }$ & 5 \\
\hline $\mathrm{P}_{3}$ & & $\sqrt{ }$ & $\sqrt{ }$ & $\sqrt{ }$ & $\sqrt{ }$ & $\sqrt{ }$ & $\sqrt{ }$ & 6 \\
\hline $\mathrm{P}_{4}$ & $\sqrt{ }$ & $\sqrt{ }$ & $\sqrt{ }$ & $\sqrt{ }$ & $\sqrt{ }$ & $\sqrt{ }$ & $\sqrt{ }$ & 7 \\
\hline $\mathrm{P}_{5}$ & $\sqrt{ }$ & $\sqrt{ }$ & $\sqrt{ }$ & $\sqrt{ }$ & $\sqrt{ }$ & $\sqrt{ }$ & & 6 \\
\hline $\mathrm{P}_{6}$ & $\sqrt{ }$ & & $\sqrt{ }$ & & & & $\sqrt{ }$ & 3 \\
\hline $\begin{array}{l}\text { Band } \\
\text { fre- }\end{array}$ & $\begin{array}{l}51 . \\
35\end{array}$ & $\begin{array}{l}97 . \\
30\end{array}$ & $\begin{array}{c}100 \\
00\end{array}$ & $\begin{array}{l}62 \\
.1\end{array}$ & $\begin{array}{l}97 . \\
30\end{array}$ & $\begin{array}{l}97 . \\
30\end{array}$ & $\begin{array}{l}97 . \\
30\end{array}$ & \\
\hline Total & & & & & & & & 33 \\
\hline
\end{tabular}

Table 6. Similarity Matrix values of 6 peroxidase banding patterns

\begin{tabular}{llllll}
\hline Zymotypes & $\mathbf{P}_{\mathbf{1}}$ & $\mathbf{P}_{\mathbf{2}}$ & $\mathbf{P}_{\mathbf{3}}$ & $\mathbf{P}_{\mathbf{4}}$ & $\mathbf{P}_{\mathbf{5}}$ \\
\hline & & & & & \\
$\mathrm{P}_{2}$ & 0.833 & & & & \\
$\mathrm{P}_{3}$ & 0.714 & 0.833 & & & \\
$\mathrm{P}_{4}$ & 0.857 & 0.714 & 0.857 & & \\
$\mathrm{P}_{5}$ & 0.714 & 0.571 & 0.714 & 0.857 & \\
$\mathrm{P}_{6}$ & 0.50 & 0.333 & 0.333 & 0.429 & 0.286 \\
\hline
\end{tabular}

Table 7. Distribution of genotypes in the zymotypes.

\begin{tabular}{|c|c|c|c|}
\hline $\begin{array}{c}\text { Zymo- } \\
\text { type }\end{array}$ & $\begin{array}{c}\text { Total no. } \\
\text { of geno- } \\
\text { types }\end{array}$ & $\begin{array}{c}\text { \% Geno- } \\
\text { types }\end{array}$ & Genotypes \\
\hline $\mathrm{P}_{1}$ & 4 & 10.81 & $\begin{array}{l}\text { CUCH-1, CUCH-2, } \\
\text { CUCH-3, CUCH-10 }\end{array}$ \\
\hline $\mathrm{P}_{2}$ & 9 & 24.32 & $\begin{array}{l}\text { CUCH-4, CUCH-5, } \\
\text { CUCH-6, CUCH-8, } \\
\text { CUCH-9, CUCH-24, } \\
\text { CUCH-25, CUCH-26, } \\
\text { CUCH-27 }\end{array}$ \\
\hline $\mathrm{P}_{3}$ & 9 & 24.32 & $\begin{array}{l}\text { CUCH-7, CUCH-11, } \\
\text { CUCH-14, CUCH-16, } \\
\text { CUCH-20, CUCH-29, } \\
\text { CUCH-30, CUCH-32, } \\
\text { CUCH-33 }\end{array}$ \\
\hline $\mathrm{P}_{4}$ & 13 & 35.14 & $\begin{array}{l}\text { CUCH-12, CUCH-13, } \\
\text { CUCH-15, CUCH-17, } \\
\text { CUCH-18, CUCH-19, } \\
\text { CUCH-21, CUCH-22, } \\
\text { CUCH-31, CUCH-34, } \\
\text { CUCH-35, CUCH-36, } \\
\text { CUCH-37 }\end{array}$ \\
\hline $\mathrm{P}_{5}$ & 1 & 2.70 & CUCH-28 \\
\hline $\mathrm{P}_{6}$ & 1 & 2.70 & CUCH-23 \\
\hline
\end{tabular}

among the members of these clusters. Minimal distance was noted between cluster-I and II (57.80) VI (59.53), indicating proximate relationship among the genotypes included in these two clusters.

Cluster-VII emerged as unique because it had the highest mean values for maximum number of yield contributing characters viz., leaf width, fruit girth, number of fruits per plant, fresh fruit weight, dry fruit weight and total fruit yield per plant (Table 4). This cluster also showed highest mean values for physiological and fruit quality characters like total chlorophyll content in 
Chandan Kumar Mondal et al. / J. Appl. \& Nat. Sci. 8( 4): 1884-1892 (2016)
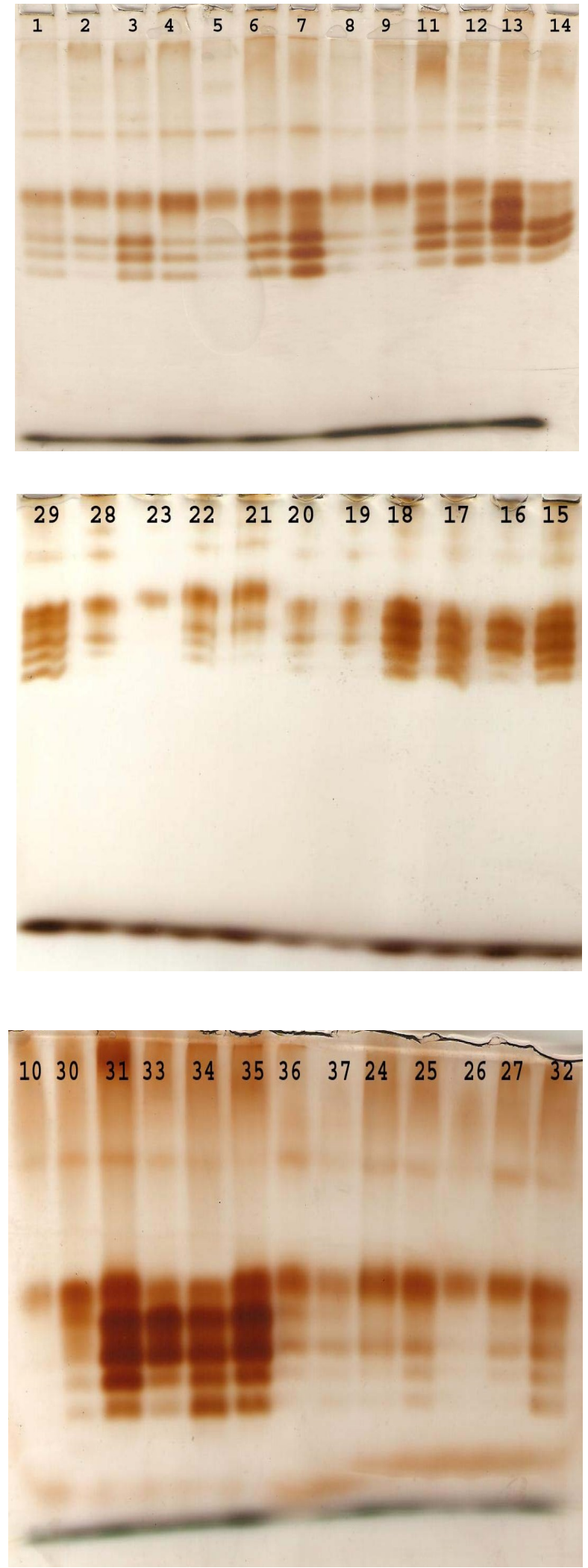

Fig. 1. Peroxidase electrophoretic banding and zymotypes.

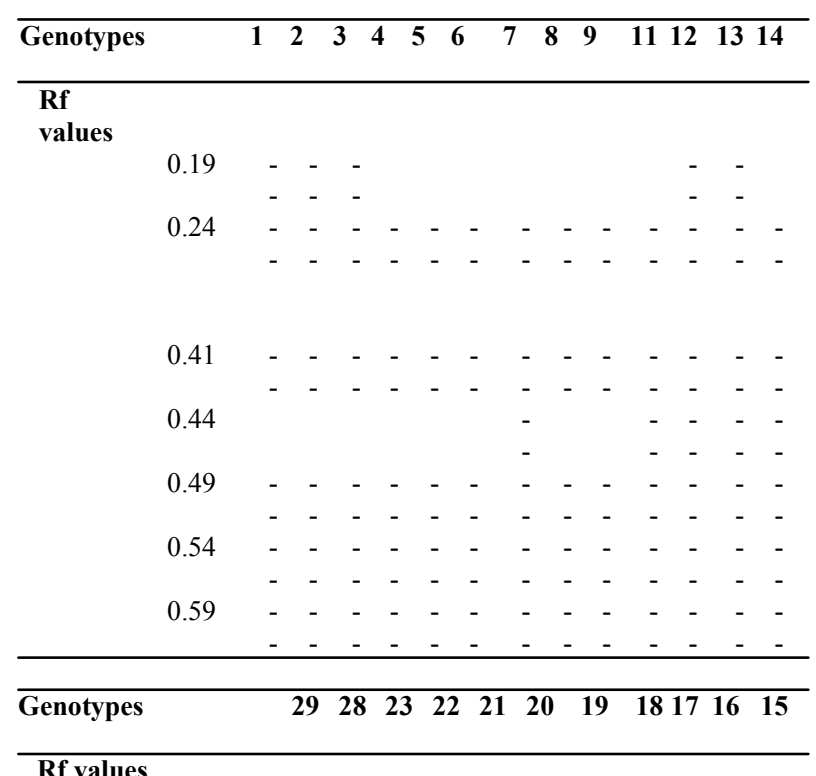

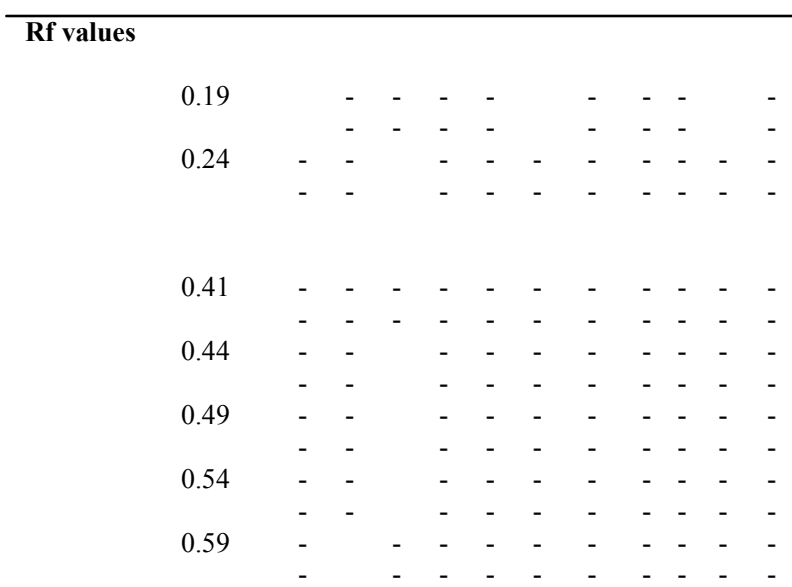

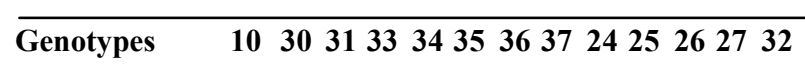

Rf val-

ues
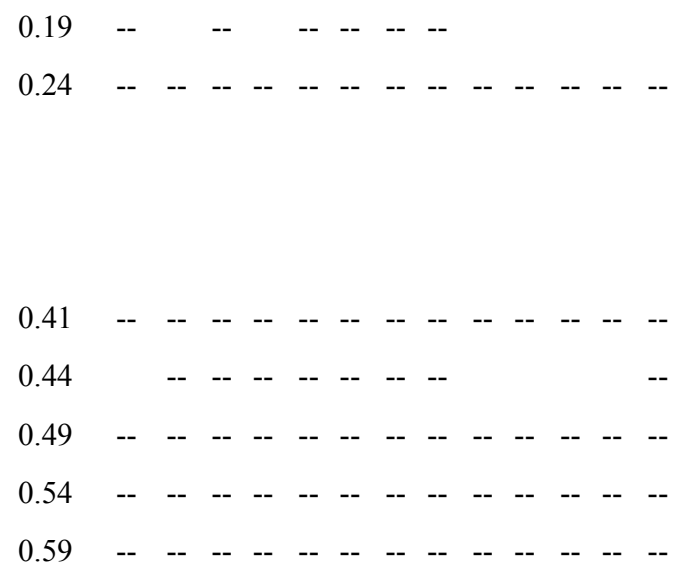

Fig. 2. Zymogram of electrophoretic pattern of peroxidase isozyme of 37 genotypes. 
green mature fruit, total carotenoid content in red ripe fruit and leaf phenol content. Cluster-I though showed highest mean value for the growth and yield related characters i.e. plant height, plant canopy width, leaf length, fruit length, fruit pedicel length and 100 seed weight, but registered as third highest for fruit yield per plant after cluster-II. High mean values for earliness with respect to seed germination, days to $50 \%$ flowering and days from fruit set to maturity were recorded in cluster-III, though this cluster failed to score substantially high mean values for other yield related traits and at the same time, recorded the lowest yield per plant. Moderate expression of all the characters were recorded in Cluster-IV and V. Cluster-VI recorded the highest mean value for two fruit quality traits i.e. ascorbic acid content and capsaicin content but mean fruit yield per plant of this cluster was very low.

Crosses involving parents belonging to most divergent clusters are expected to give maximum heterosis and create wide variability in genetic architecture. However, for a practical plant breeder, the objective is not only obtaining high heterosis but also to achieve high level of production within the shortest possible time. In the present study maximum distance exists between cluster-V \& cluster-VII. However, considering intercluster distance and other agronomic performances, crosses between the members of cluster-II and clusterVII might exhibit high heterosis and is also likely to produce new recombinants with desired traits.

Isozyme analysis (analysis through poly-morphic banding): Study on genetic diversity in terms of isozyme poly-morphism have been extensively utilized in different vegetable crops viz., brinjal (Ali et al., 2011), tomato (Gunaseelan et al., 2011; Evans and Allridge, 1965), potato (Beatriz et al., 2001), radish (Ivy et al., 2010), and field crops like cotton (Farooq and Sayyed, 1999), soybean (Buttery and Buzzel, 1968; Brim et al, 1969) etc. but in chili pepper, such studies on isozymes are very limited (Onus \& Pickersgill, 2000; Barrera et al., 2005; Nitesh et al., 2010).

In the present study, peroxidase electrophoretic banding, zymogram following electrophoretic banding pattern and zymotypes of the 37 genotypes have been presented in Figure $1 \& 2$ and in Table 5. A total of seven bands of peroxidase were obtained ranging from $\mathrm{Rf} 0.19$ to $\mathrm{Rf}$ 0.59 . The number of bands varied with the genotypes. It is apparent from the Figure- 2 and Table- 5 that the band with $\mathrm{Rf}$ value 0.41 appeared in all the genotypes $(100 \%$ band frequency) while the band with Rf value 0.19 appeared in minimum (19) number of genotypes (51.25\% band frequency). Only 23 genotypes showed the band with $\mathrm{Rf}$ value $0.44(62.10 \%$ band frequency). Frequency of other 4 bands with $\mathrm{Rf}$ values $0.24,0.49,0.54$ and 0.59 was $97.30 \%$, however their appearance varied with the genotypes.

Similarity matrix values of 6 peroxidase banding pattern (Table 6) suggested that the Zymotypes $\mathrm{P}_{1}$ and $\mathrm{P}_{4} ; \mathrm{P}_{4}$ and $\mathrm{P}_{3} ; \mathrm{P}_{4}$ and $\mathrm{P}_{5}$ were close to each other in similar intensity
(Similarity index value 0.857). The Zymotype $\mathrm{P}_{6}$ was farthest from $\mathrm{P}_{5}$ (Similarity index 0.286 ) followed by $\mathrm{P}_{3}$ and $\mathrm{P}_{2}$ (Similarity index 0.333 ).

Distribution of the peroxidase bands grouped the 37 genotypes into 6 zymotypes (Table 7). The Zymotype $\mathrm{P}_{4}$ was having all the 7 bands and also maximum number of thirteen genotypes in it. Three Zymotypes $\left(\mathrm{P}_{1}, \mathrm{P}_{3}\right.$ and $\left.\mathrm{P}_{5}\right)$ were having 6 peroxidase bands, with variation in their banding pattern. Zymotype $\mathrm{P}_{1}$ was devoid of band with Rf value 0.44 and contained 4 genotypes in it. Zymotype $\mathrm{P}_{3}$ containing 9 genotypes had all bands except band with $\mathrm{Rf}$ value 0.19 . Zymotype $\mathrm{P}_{5}$ containing 1 genotype was lacking the last band with $\mathrm{Rf}$ value 0.59 . Zymotype $\mathrm{P}_{2}$ having 9 genotypes in it, had 5 bands excluding 2 bands with Rf 0.19 and 0.40 . The last Zymotype $\mathrm{P}_{6}$ containing only one genotype had only 3 bands i.e. Rf 0.19 , Rf 0.41 and Rf 0.59 .

Multivariate analysis and Isozyme analysis: It was clear from the present study that overall 7 clusters were formed with multivariate analysis employing 22 quantitative traits (Table 2) whereas 6 zymotypes were obtained with peroxidase isozyme analysis (Table 7). The number of clusters obtained by multivariate analysis and peroxidase isozyme analysis were almost same but the genotypes included in each individual cluster varied. Zymotype $\mathrm{P}_{1}$ has been formed with 4 genotypes of Cluster II. Other members of Cluster II were grouped in Zymotype $\mathrm{P}_{2}$, along with some members from Cluster III, IV, VI and VII. This phenomenon may be due to the environmental influence for the expression of quantitative traits. Almost similar result was recorded by Singh et al. (2010) in blackgram in which 8 clusters were formed with quantitative traits analysis whereas 9 clusters were obtained with SDS-PAGE analysis of total seed storage protein.

\section{Conclusion}

In the present study thirty seven genotypes of chilli were grouped into seven clusters and six zymotypes irrespective of their origin. From this study, it may be concluded that a wide range of variation for almost all the economically important traits are present in this crop. This implies a good possibility of breeding through hybridization programme or direct use of promosing genotypes as variety for successful chilli production. Distant parents are able to exert high heterosis. Considering this theme and variability and diversity analysis of the genotypes, $\mathrm{CUCH}-4$ from Cluster-II (\& Zymotype- $\mathrm{P}_{2}$ ) and CUCH-31, CUCH-34 and CUCH-35 from Cluster-VII (\& Zymotype-P4) were identified as promising genotypes. Further genetic studies may also be carried out using two or more promising genotypes, either through diallel or by line $\mathrm{x}$ tester analysis.

It also emerged that $72.97 \%$ of the total genotypes (i.e. 27 genotypes; 6 from $\mathrm{C}$-IV to $\mathrm{P}_{4}, 4$ each from $\mathrm{C}$-II to $\mathrm{P}_{1}$ and C-IV to $\mathrm{P}_{3}, 3$ each from C-II to $\mathrm{P}_{2}, \mathrm{C}$-IV to $\mathrm{P}_{2}$ and $\mathrm{C}$-VII to $\mathrm{P}_{4}, 2$ each from $\mathrm{C}$-VII to $\mathrm{P}_{2}$ and $\mathrm{C}-\mathrm{VII}$ to $\mathrm{P}_{3}$ ) grouped almost similarly under both multivariate analysis and isozyme polymorphism. So, it can be said that these two methods of determining diversity are complemen- 
tary to each other and should be carried out simultaneously to determine genetic diversity in a more authentic manner. It is pertaining to say that isozyme polymorphism for chili cultivars could be used for cultivar registration which could be helpful for chili breeders.

\section{REFERENCES}

Ali, M. (ed.). (2006). Chili (Capsicum spp.) Food Chain Analysis: Setting Research Priorities in Asia. Shanhua, Taiwan: AVRDC - The World Vegetable Center, Technical Bulletin No. 38, AVRDC Publication 06-678. pp 15. In http://www.avrdc.org/pdf/TB38.pdf

Ali, Z., Xu, Z.L., Zhang, D.Y., He, X.L., Bahadur, S. and Yi, J.X. (2011). Molecular diversity analysis of eggplant (Solanum melongena) genetic resources. Genet. Mol. Res., 10 (2): 1141-1155

Aniel Kumar, O., Rupavathi, T. and Subba Tata, S. (2013). Genetic Variation of Isozyme Polyphenol Oxidase (PPO) Profiles in Different Varieties of Capsicum annuum L. Notulae Scientia Biologicae, 5(4):454-457

Anonymous (2007). FAO Production Yearbook, p: 333. Rome, Italy

Anonymous (2012). Crop report 2011/12, Oilseeds and Spices. P:6. http://www.agrocrops.com/ crop-report2012.pdf

Barrera, L.Q., Garcia, M.C., Giraldo, M.C. and Melgarejo, L.M. (2005). Isozyme characterization of Capsicum accessions from the Amazonian Colombian collections. Revista Colombiana De Biotecnologia, 1: 59-65

Beatriz Helena Gomes Rocha, Eliane Augustin, João Baptista da Silva and Judith Viégas (2001). Isoenzymatic variability in wild potatoes. Pesq. Agropec. Bras., 36 (5): 781-791

Bhat, K.V., Bhat, S.R. and Chandel, K.P.S. (1992a). Survey of isozyme polymorphism for clonal identification in Musa I. Esterase, acid phosphatase, and catalase. $J$. Horti. Sci., 67 (4): 501-508

Bhat, K.V., Bhat, S.R. and Chandel, K.P.S. (1992b). Survey of isozyme polymorphism for clonal identification in Musa II. Peroxidase, superoxide dismutase, shikimate dehydrogenase, and malate dehydrogenase. J. Horti. Sci., 67(6): 737-743

Brewer, G.J. and Sing, C.F, (1970). An Introduction to Isozyme Techniques, Academic Press, New York.

Brim, C.A., Usanis, S.A. and Tester, C.F. (1969). Organ specificity and genotype differences in isoperoxidases of soybeans. Crop Sci., 9: 843-845

Buttery, B.R. and Buzzel, R.I. (1968). Peroxidase activity in seeds of soybean varieties. Crop Sci., 8: 722-725

Evans, J.J. and Allridge, N.A. (1965). The distribution of peroxidases in extreme dwarf and normal tomato (Lycopersicon esculentum). Phytochemistry, 8: 499-503

Farooq, S. and Sayyed, H. (1999). Isozyme markers in cotton breeding-II: Inter and intra varietal variation in the activity of isozymes of the enzyme peroxidase as affected by area of cotton cultivation. Pak. J. Bot., 31 (2): 347-359

Gunaseelan, C., Suganyadevi, P., Rajasabapathy, R. and Ruban, P. (2011). Differentiation of Hybrid (COTH2) and wild (CO3) varieties of tomato (Lycopersicon esculentum) using protein and peroxidase isozyme profile. Res. \& Rev., 1 (2): $1-5$

Gupta, C.H.G., Lakshmi, N. and Srivalli, T. (1997). Analysis of isozyme patterns (peroxidase) of Capsicum hybrids through PAGE. Capsicum and Eggplant Newsletter. 16: 64-67

IPGRI, AVRDC and CATIE. (1995). Descriptors for Capsicum ( Capsicum spp.). International Plant Genetic Resources Institute, Rome, Italy; the Asian Vegetable Research and Development Center, Taipei, Taiwan, and the Centro Agronómico Tropical de Investigación y Enseñanza, Turrialba, Costa Rica.

Ivy, N.A., Biswas, M.S., Rasul, G., Hossain, T. and Mian, M.A.K. (2010). Variations of genotypes of radish at molecular level using isozyme analysis for the identification of self-incompatible lines. Global J. Biotech. Biochem, 5 (1): 19-26

Lahbib, K., Bnejdi, F. and Gazzah, E.I. (2012). Genetic diversity evaluation of pepper in Tunisia based on morphologic characters. Afr. J. Agric. Res., 7 (23): 34133417

Lebot, V., Aradhya, M.K. and Manshardt, R.M. (1991). Geographic survey of genetic variation in kava (Piper methysticum Forst. F. and P. wichmanii C. DC.). Pacific Sci., 45 (2): 169-185

Mahalanobis, P. (1936). On the generalized distance in statistics. Proc. Nat. Inst. Sci., (India), 12: 49-55

Murty, B.R. and Arunachalam, V. (1966). The nature of genetic divergence in relation to breeding system in crop plants. Indian J. Genet, 26A: 188-198

Narasimhayya, G. and Venkatarao, C. (1974). Classification of the varieties of cigarette tobacco using D2 statistic. Indian J. Agric. Sci., 44: 660 - 664

Nitesh, L., Dilraj, K., Patel, N.J. and Talati, J.G. (2010). Varietal identification of chilli (Capsicum annuиm L.) by electrophoretic technique. Indian J. Agric. Biochem. 23 (1): 36-40

Nourish, M.J. (1993). SPSS for Windows-Professional Statistics; Release 6.0 SPSS Inc. 444N. Michigan Avenue, Chicago, Illinoise, 6061

Onus, A.N. and Pickersgill, B. (2000). A study of selected isozymes in Capsicum baccatum, Capsicum eximium, Capsicum cardenasii, and two interspecific F1 hybrids in Capsicum species. Turk. J. Bot, 24: 311-318

Pandey, G. and Dobhal, V. K. (1993). Multivariate analysis in chilli (C. annuum L.). J. Spices Aromatic Crops, 2 (12): 71-74

Peeraullee, N. and Ranghoo-Sanmukhiya, V.M. (2013). Assessment of genetic diversity in local chilli (Capsicum annuum) varieties in mauritius. International Journal of Agriculture and Biology, 12: 387

Powers, H.R., Lin, D. Jr. and Hubbes. (1988). Interspecific and intraspecific differentiation within the genus Cronartium by isozyme and protein pattern analysis. $P l$. Dis., 73: 691-694

Singh, A.K., Mishra, A. and Shukla, A. (2010). Genetic evaluation and identification of genetic donors in blackgram (Vigna mungo) revealed by agromorphological traits and seed storage protein analysis. World Appl. Sci., J. 10 (4): 477-488

Sreelathakumary, I. and Rajamony, L. (2004b). Genetic divergence in chilli (Capsicum annuum L.) Indian $J$. Hort., 62 (2):137-139

Varalakshmi, B. and Babu, K. H. (1991). Genetic divergence, heritability and genetic advance in chilli $(C$. annuum L.). Indian J. Genet., 56(2): 174-178. 